\title{
Determination of Paeonol in Cynanchum paniculatum by high Performance Capillary Electrophoresis
}

\author{
Hai-Xing Liu ${ }^{a}$, Xiao-Dong Jiang ${ }^{b}$, Xia Wang ${ }^{c}$, Lin-Tong Wang ${ }^{d}$ and Yun-Chen \\ Zhang $^{\mathrm{e}}$
}

Chemistry \& Chemical and Environmental Engineering College, Weifang University, Weifang 261061, P.R. China

ahaixingliu@tom.com, ${ }^{b}$ 2_haixingliu@tom.com, ${ }^{\mathrm{c}} 3$ _haixingliu@tom.com, ${ }^{\mathrm{d}} 5$ _haixingliu@tom.com, 4_haixingliu@tom.com

Keywords: HPCE, Cynanchum paniculatum, paeonol

Abstract. This design uses High Performance Capillary Electrophoresis (HPCE) to determine the Paeonol's content in Cynanchum paniculatum. Electrophoresis separation controlled conditions for uncoated fused silica capillary column $(75 \mu \mathrm{m} \times 52 / 60 \mathrm{~cm})$ injection height $7.5 \mathrm{~cm}$, and using a concentration of $40 \mathrm{mmol} / \mathrm{L}$ borax solution as buffer. Using separate voltage $20 \mathrm{KV}$ to detect wavelength $270 \mathrm{~nm}$, temperature is $20^{\circ} \mathrm{C}$, and the injection time control $10 \mathrm{~s}$. The Paeonol is linear relationship $(\mathrm{r}=0.998)$ within concentration of $3 \sim 400 \mathrm{mg} / \mathrm{L}$, and measuring 6 times its average recovery was $92.35 \%$, RSD2.4\%. After the contents were measured 7 times, Paeonol contain was $9.9 \mathrm{mg} / \mathrm{g} \mathrm{RSD}=6.6 \%$. Conclusion for this design is that the method is simple, accurate and efficient with good reproducibility for the determination of paeonol in Cynanchum paniculatum determination.

\section{Introduction}

Cynanchum paniculatum is large used as traditional Chinese medicine and has been utilized for rheumatoid arthritis, traumatic injuries, urticaria, eczema and sedative. Paeonol, the effective component of the herb, has a variety of biological activities such as antibacterial, anti-inflammatory, relieving pain, inhibition of anaphylactic reaction, anti-diabetic effect and inhibition of platelet aggregation [1,2]. Guo et al [3] established a method for determination of paeonol in Cynanchum paniculatum and Paeonol injection. Venusil XBP-C 18 (200mmX $4.6 \mathrm{~mm}, 5 \mu \mathrm{m})$ column and methanol-water(70:30, v/v)as mobile phase were used. Li et al [4] established a method by RP-HPLC for the determination of paeonol of Cynanchum paniculatum. Using ZORBAX SB-C ${ }_{18}(4.6150 \mathrm{~mm}, 5 \mu \mathrm{m})$, the mobile phase was a mixture of methanol-water(50:50). Qin et al [5] optimized extraction method of Cynanchum paniculatum in Zhenggu compound. With the paeonol content as index, which was determined by HPLC, effect of grinding degree, ethanol concentration and extraction time on extraction technology was studied by orthogonal test. Du et al [6] studied chemical constituents of essential oil from Cynanchum paniculatum. The essential oil from Cynanchum paniculatum was extracted by simultaneous distillation and extraction, then separated and analysed by C-MS. About 20 compounds were separated, the identified components receive $99.4 \%$ of all the essential oil. Peonol is the large chemical constituents in the oil, the othem are Palmitic acid and Oleie acid. LOU et al [7] optimized the process conditions for extraction technology of the paeonol from Cynanchum paniculatum with nlicrowave. A HPLC method for the determination of chlorogenic acid content in Cynanchum paniculatum was established by $\mathrm{Yu}$ [8], Using 70\% methyl alcohol to extract chlorogenic acid from Cynanchum paniculatum by Soxhlet extraction technology. The essential oil from root of Cynanchum paniculatum was analyzed by ZHAO et al [9] using SPME/GC/MS. The components in the essential oil were quantitatively determined by peak area normalization. In this paper, the paeonol content in Cynanchum paniculatum was determined by High Performance Capillary Electrophoresis. 


\section{Experimental section}

\section{Instruments and Reagents}

Experimental instruments: CL-1030-type high performance capillary electrophoresis (Beijing Cailu Scientific Instrument Co., Ltd.); HW2000-type chromatography workstation (Nanjing Qianpu Software Ltd.); Capillary (75 $\mu \mathrm{m}$ inner diameter, $60 \mathrm{~cm}$ overall length, $52 \mathrm{~cm}$ effective length) from Hebei Yongnian Ruifeng Chromatographic Devices Co., Ltd.).

Paeonol (Chinese Drugs and Biological Products); Cynanchum paniculatum (Weifang Bencaotang pharmaceutical Co., Ltd.); Other reagents used in the experiments were all analytical grade; Double-distilled water was used.

\section{Experimental Methods}

Before the start of the experiment, capillary was successively washed with $1 \mathrm{~mol} \cdot \mathrm{L}^{-1}$ hydrochloric acid solution, double-distilled water, $1 \mathrm{~mol} \cdot \mathrm{L}^{-1}$ sodium hydroxide solution, double-distilled water, buffer solution, each for $8 \mathrm{~min}$. After three times running, capillary was cleaned again using the above method.

Measurements were carded out at $20 \mathrm{kV}$ voltage and $20^{\circ} \mathrm{C}$ experimental temperature. UV detection wavelength was $270 \mathrm{~nm}$. Injection time was $10 \mathrm{~s}(7.5 \mathrm{~cm}$ height difference).

\section{Sample Preparation}

Cynanchum paniculatum sample solution: Cynanchum paniculatum powder was accurately weighed $1.4129 \mathrm{~g}$, added $30 \mathrm{~mL}$ water with $30 \%$ ethanol, cold soak time of $24 \mathrm{~h}$, filtered, washed and set the volume to $50 \mathrm{~mL}$ that was the Cynanchum paniculatum sample solution.

paeonol standard solution: paeonol was accurately weighed $0.0012 \mathrm{~g}$, added $3 \mathrm{~mL}$ water with $25 \%$ ethanol.

\section{Results and Discussion}

\section{Selection electrophoresis conditions}

Based on past experiment experience, we chose $40 \mathrm{mmol} / \mathrm{L}$ borax solution as a running buffer solution.

According to the literature, paeonol maximum absorption wavelength was at $274 \mathrm{~nm}$, so we chose the $270 \mathrm{~nm}$ detection wavelength.

\section{Quantitative analysis Standard curve}

First, paeonol standard solution that the concentration were $0.4,0.2,0.1,0.05,0.025,0.0125$, $0.00625,0.003125 \mathrm{mg} / \mathrm{mL}$ was prepared. Each standard solution was run for three times under the above electrophoresis conditions and the results averaged. The chromatogram of paeonol standard solution was showed in Figure 1. Taking concentration as the abscissa and peak area as the ordinate, the standard curve was drew. Linear regression equation of paeonol (peak area: $\mathrm{y} \mu \mathrm{V} \bullet \mathrm{s}$, density: $\mathrm{x}$ $\mathrm{mg} / \mathrm{mL})$ and the linear range was as follows: $\mathrm{y}=-3147.5+420341 \mathrm{x}(\mathrm{r}=0.998), 0.003-0.4 \mathrm{mg} / \mathrm{mL}$. 


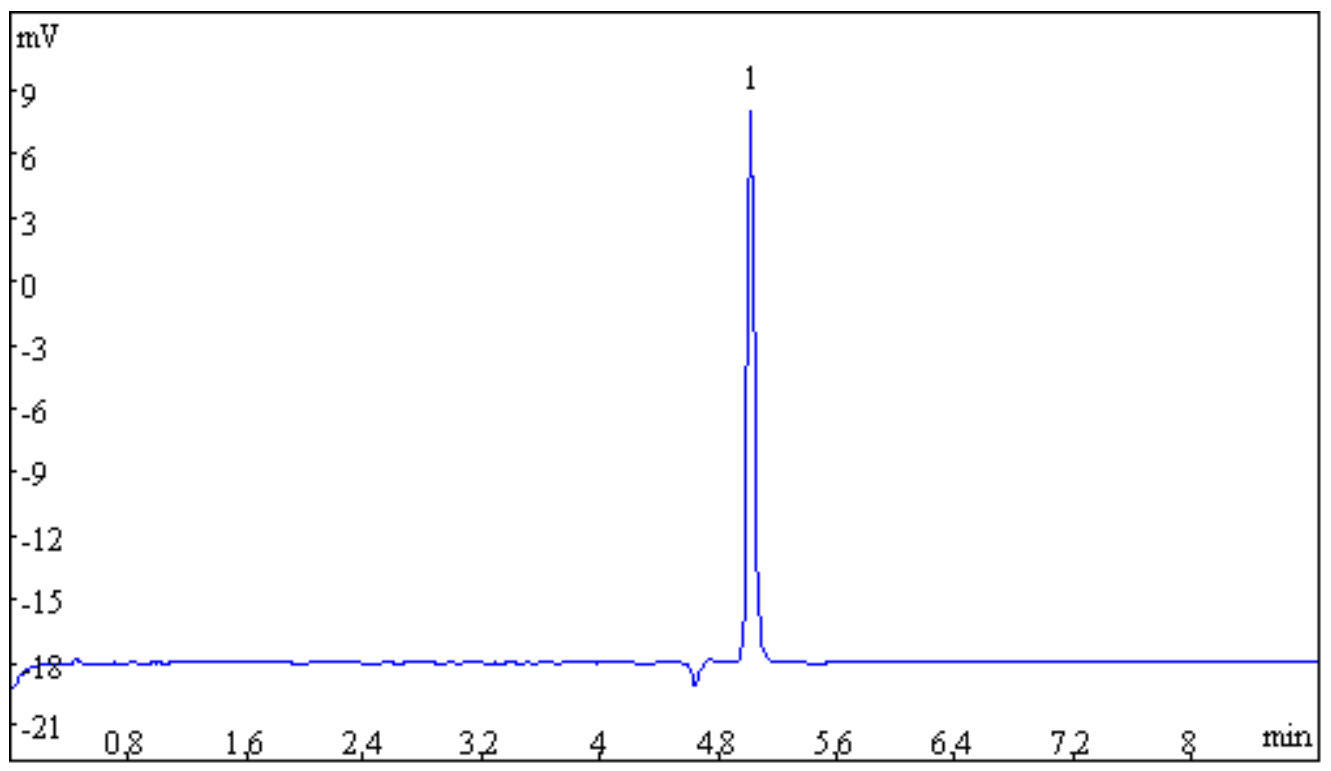

Fig.1 Electrophorogram of paeonol standard solution1-paeonol

\section{Precision test}

paeonol standard solution precisely drew and continuously injected for six times under electrophoretic separation conditions, the RSD of paeonol peak area was 3.3\%, indicating good precision.

\section{Determination of sample content}

Under selected electrophoresis conditions, Cynanchum paniculatum sample solution was run. Separation chromatogram of the Cynanchum paniculatum sample solution was showed in Figure 2. Measured paeonol content in Cynanchum paniculatum was $9.9 \mathrm{mg} / \mathrm{g}(\mathrm{RSD}=6.6 \%)(\mathrm{n}=6)$.

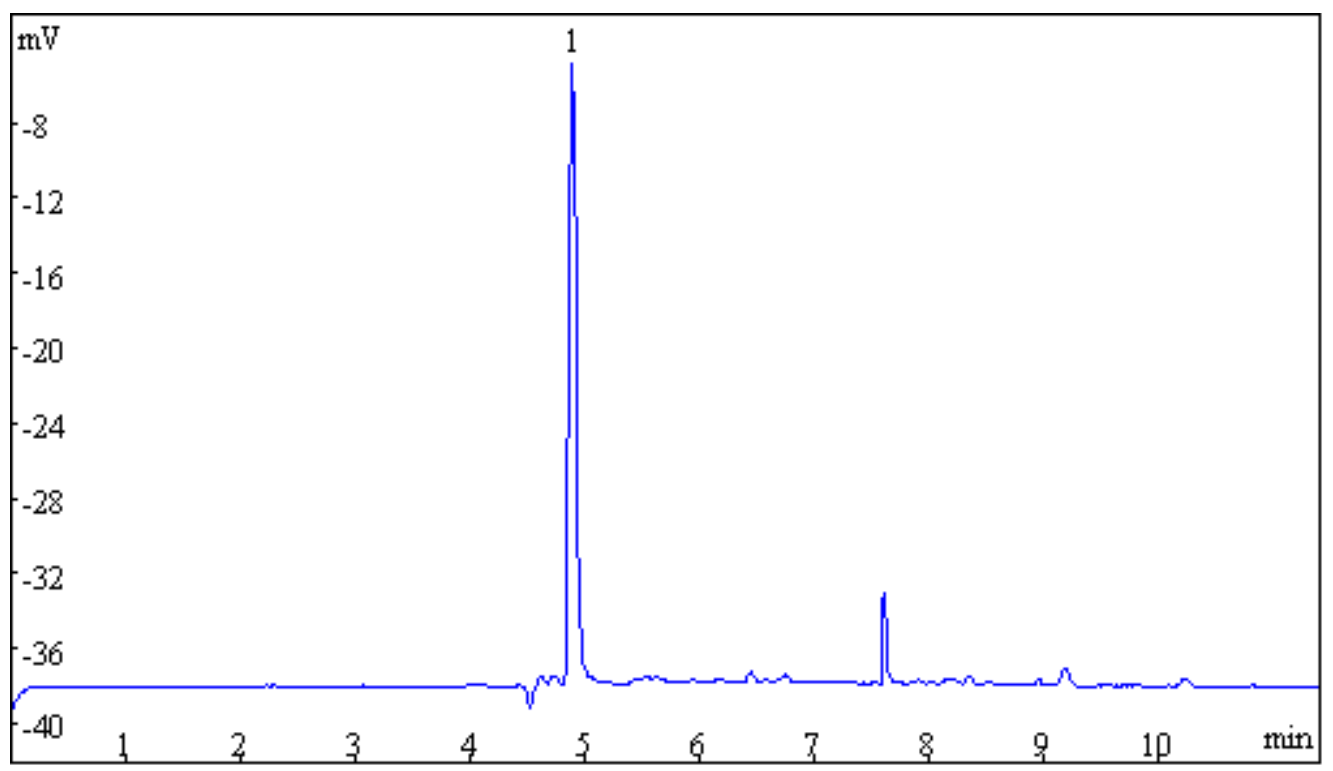

Fig.2 Electrophorogram of Cynanchum paniculatum sample solution 1-paeonol 


\section{Recovery}

After determination for four times, the recovery of paeonol in Cynanchum paniculatum sample was in the range of $90 \%-95.7 \%(n=6)$.

\section{Acknowledgments}

This study were supported by the Natural Science Foundation of Shandong Province (No. ZR2010BL025), Open Project of State Key Laboratory of Supramolecular Structure and Materials (No. sklssm201323)(Jilin University), State Key Laboratory of Inorganic Synthesis and Preparative Chemistry (No. 2011-13)(Jilin University).

\section{References}

[1] Lau CH, Chan CM, Chan YW, Lau KM, Lau TW, Lam FC, Law WT, Che CT, Leung PC, Fung KP, Ho YY, Lau CBS, Phytomedicine, 2007, 14, 778-784

[2] Ronghua Jin, Ling Fan, Xiaoning An, Chromatographia, 2011, 73, 787-792

[3] Lin GUO, Dongjun GUO, CHINA FOREIGN MEDICAL TREATMENT (In Chinese), 2011, $29,4-5$

[4] Ke Li, Yon-xiu Qi, YU-qin Li, Cai-hong Liu, Bao-xiu Jia, JOURNAL OF TAISHAN MEDICAL COLLEGE (In Chinese), 2010, 31(11), 856-858

[5] Bao QIN, Qin LI, Huan DENG, Wen-jia JIANG, Dong-xiao WEI, Dan-dan TONG, Qin HE, Chinese Journal of Experimental Traditional Medical Formulae (In Chinese), 2013, 19(4), 47-49

[6] Yue-zhong Du, Zi-jing Wu, Zhe Deng, GINSENG RESEARCH (In Chinese), 2011, 4, 41-42

[7] Fang-ming LOU, Qun-fang LI, Jing QIAN, ACTA ACADEMIAE MEDICINAE ZUNYI (In Chinese), 2009, 32(5), 502-504

[8] Jia-ping Yu, Chinese Journal of Veterinary Drug (In Chinese), 2012, 46(1), 34-36

[9] Chao ZHAO, Zai-bo YANG, Qian-jun ZHANG, Xin ZHOU, Hua-guo CHEN, Min LI, Journal of Guizhou University (In Chinese), 2007, 24(4), 407-409 